$\xi=$ 国

\title{
RSM And ANFIS Based Parameters Prediction of Robot Using GRA
}

\author{
P. Gopu ${ }^{1 *}$, M. Dev Anand ${ }^{2}$ \\ ${ }^{1}$ Assistant Professor, Department of Mechanical Engineering Sandwich, Lord Jegannath College of Engineering and Technology, PSN \\ Nagar, Ramanathichanputhur, Tamil Nadu, India. \\ ${ }^{2}$ Professor and Dean, Department of Mechanical Engineering, Noorul Islam Centre for Higher Education, Kumaracoil, Tamilnadu, \\ India. \\ *Corresponding author E-mail:gopu91@hotmail.com
}

\begin{abstract}
Ability of robot arm manipulation must be highly accurate and repeatable one. Performance uncertainty is causes by some noise factor. The effects of these factors were model to reduce the uncertainty of the robotic arm performance. In this paper highlights the prediction of output parameters robot cell data like X, Y and Z axis through Response Surface Methodology (RSM) and Adaptive Neuro Fuzzy Inference System (ANFIS) for reduce the performance variation of the robot. The input kinematic parameters like $\theta 1, \theta 2, \theta 3, \theta 4, \theta 5$ has been considered and the output multi objective parameters $\mathrm{X}, \mathrm{Y}$ and $\mathrm{Z}$ axis has been converted in to single objective parameter. The graph which plots between parameters and the output response indicates the influence of the every single parameter for the performance output contribution. From the simulated values of Response Surface Methodology and Adaptive Neuro Fuzzy Inference System, the percentage of error obtained in Adaptive Neuro Fuzzy Inference System has minimum one when compared with Response Surface Methodology of prediction.
\end{abstract}

Keywords: Robot, response surface methodology, adaptive neuro fuzzy inference system.

\section{Introduction}

There is a need for the prediction of robot movement in the modern manufacturing sectors as well as other industries having robotic technology. The manipulator of the robotic arm must be précised and repeatable one always for getting a certainty performance of the robot. The trajectory of the robot is predicting for unavoidable accident prevention. However the prediction is fully based on the previous experience of the robot movement observation.

Shiakolas et al. (2002) has been discussed the factors which affects the repeatability and accuracy characteristics of the industrial robot. Rout et al. (2005) has been synthesized the robot parameters using Taguchi method of optimization. Simon et al. (2009) has predicted the robot movements using generative models. The obtained results confirmed that the prediction accuracy and the recognition speed mainly based on the model match the observed behaviour of robot. Jianhao et al. (2013) was deduced a kinematic error relative to the end actuator of the robot based on D-H algorithm. Trang et al. (2016) were allocated the tolerances into robot parts by introduced a technique by using the Generalized Reduced Gradient algorithm optimization. The effect of link and joint tolerances considered simultaneously by the developed model and based on the kinematic reactions nature instruction for tolerance of each link has been determined. The ultimate aim of this research work is to identify the effect of the robot parameters considered using Adaptive Neuro Fuzzy Inference System as well as Response Surface Methodology. However for reducing the cycle time of the prediction work in both tools, there is a need for shortening the number of cycles. In this work the number of observed output response output is three and these multi responses has been converted in to single response using Grey Relation Analysis technique.

\section{Experimental work}

The robotic arm used for carried out an experimental work is SCORBOT $5 \mathrm{u}$ plus. The input influencing parameters of joint coordinates considered for robot movement are $\theta 1, \theta 2, \theta 3, \theta 4, \theta 5$ and the corresponding output response robot cell data carried out is position of $\mathrm{X}, \mathrm{Y}$ and $\mathrm{Z}$ which is tabulated in the below table 1 . Response Surface Methodology plays an effective role for modelling the entire work through generating the equation. It is a combined form of both statistical and mathematical technique used for analysis. Same way Adaptive Neuro Fuzzy Inference System is one of the recently developed artificial intelligence tool for prediction of the process. It has a great advantage of Artificial Neural Network as well as Fuzzy logic for training the network by minimizing the error and generates the Fuzzy rules by adapting based on the design requirement.

Table 1: Input Parameters and their Output Responses

\begin{tabular}{|c|c|c|c|c|c|c|c|c|}
\hline \multirow{2}{*}{$\begin{array}{l}\text { Sl. } \\
\text { No }\end{array}$} & \multicolumn{5}{|c|}{ Joint Coordinates } & \multicolumn{3}{|c|}{ Robot Cell Data } \\
\hline & $\boldsymbol{\theta}_{1}$ & $\theta_{2}$ & $\theta_{3}$ & $\boldsymbol{\theta}_{4}$ & $\theta_{5}$ & $\mathbf{X}(\mathbf{m}$ & $\mathbf{Y}(\mathbf{m}$ & $\mathbf{Z}(\mathbf{m}$ \\
\hline 1. & 0 & - & 95.03 & 88.8 & 0 & 169.0 & 0 & 504.3 \\
\hline 2. & 0 & -8.93 & 107.8 & - & 0 & 200 & 0 & 20 \\
\hline 3. & 0 & -8.88 & 89.59 & 9.29 & 0 & 270.0 & 0 & 20.01 \\
\hline 4. & 0 & -2.95 & 65.09 & 27.8 & 0 & 340 & 0 & 20 \\
\hline 5. & 45 & -9.35 & 105.0 & - & 45.0 & 149.9 & 149.9 & 19.99 \\
\hline 6. & 45 & -6.17 & 76.21 & 19.9 & 45.0 & 220.0 & 220.0 & 20.01 \\
\hline 7. & 45 & 14.78 & 20.48 & 54.7 & 45.0 & 290 & 290 & 20.01 \\
\hline 8. & 67.1 & -9.63 & 100.8 & - & 0 & 88.91 & 211.4 & 20.01 \\
\hline
\end{tabular}



\begin{tabular}{|l|l|l|l|l|l|l|l|l|}
\hline 9. & 21.5 & -4.43 & 69.91 & 24.5 & 0 & 305.1 & 120.5 & 20.02 \\
\hline
\end{tabular}

\section{Single objective conversion}

For converting the multiple objectives in to a single objective Grey Relation Analysis has been carried out and the three step procedures for Grey Relation Analysis were mentioned below.

(i) Initially the three output responses like $\mathrm{X}, \mathrm{Y}$ and $\mathrm{Z}$ were normalized by using the equation 1 .

$\mathrm{Y}_{\mathrm{i}}=\left(\mathrm{X}_{\mathrm{i}}-\right.$ Minimum of $\left.\mathrm{X}_{\mathrm{i}}\right) /\left(\right.$ Maximum of $\mathrm{X}_{\mathrm{i}}$-Minimum of $\left.\mathrm{X}_{\mathrm{i}}\right)$

Where

$\mathrm{Y}_{\mathrm{i}}$ is the normalized output value

$\mathrm{X}_{\mathrm{i}}$ is the actual output values

$\mathrm{i}=1,2,3,4 \ldots \mathrm{n}$

Table 2: Normalized Output Responses

\begin{tabular}{|l|l|l|l|l|l|l|}
\hline \multirow{2}{*}{$\begin{array}{l}\text { Sl. } \\
\text { No. }\end{array}$} & \multicolumn{3}{|l|}{ Robot Cell Data (Actual) } & \multicolumn{2}{l|}{ Robot Cell Data (Normalized) } \\
\hline $\mathbf{1 .}$ & $\mathbf{X}(\mathbf{m m})$ & $\mathbf{Y}(\mathbf{m m})$ & $\mathbf{Z}(\mathbf{m m})$ & $\mathbf{X}(\mathbf{m m})$ & $\mathbf{Y}(\mathbf{m m})$ & $\mathbf{Z}(\mathbf{m m})$ \\
\hline $\mathbf{2 .}$ & 200 & 0 & 504.33 & 0.354372 & 0 & 1 \\
\hline $\mathbf{3 .}$ & 270.01 & 0 & 20 & 0.491353 & 0 & $2.06 \mathrm{E}-05$ \\
\hline $\mathbf{4 .}$ & 340 & 0 & 20.01 & 0.801008 & 0 & $4.13 \mathrm{E}-05$ \\
\hline $\mathbf{5 .}$ & 149.99 & 149.99 & 19.99 & 0.270575 & 0 & $2.06 \mathrm{E}-05$ \\
\hline $\mathbf{6 .}$ & 220.01 & 220.01 & 20.01 & 0.579858 & 0.517207 & 0 \\
\hline $\mathbf{7 .}$ & 290 & 290 & 20.01 & 0.889425 & 1 & 4.138655 \\
\hline $\mathbf{8 .}$ & 88.91 & 211.44 & 20.01 & 0 & 0.729103 & $4.13 \mathrm{E}-05$ \\
\hline $\mathbf{9 .}$ & 305.13 & 120.56 & 20.02 & 0.956345 & 0.415724 & $6.19 \mathrm{E}-05$ \\
\hline $\mathbf{1 0 .}$ & 315 & 247 & 190 & 1 & 0.851724 & 0.351014 \\
\hline
\end{tabular}

(ii) Next step is carried out the Grey Relation Coefficient (GRC) for the normalized output responses using the equation 2 and which is tabulated in the below table 3 .

$\mathrm{C}=\left(\right.$ Minimum $\mathrm{Y}_{\mathrm{i}}+\mathrm{D}$ Maximum $\left.\mathrm{Y}_{\mathrm{i}}\right) /\left(\mathrm{Y}_{\mathrm{i}}+\mathrm{D}\right.$ Maximum $\left.\mathrm{Y}_{\mathrm{i}}\right)$

Where

$\mathrm{C}$ is the grey relation coefficient

$\mathrm{D}$ is the distinguishing coefficient ranges $(0 \leq \mathrm{D} \leq 1)$

Table 3: GRC for the Normalized Output Responses

\begin{tabular}{|l|l|l|l|l|l|l|}
\hline \multirow{2}{*}{$\begin{array}{l}\text { S. } \\
\text { No. }\end{array}$} & \multicolumn{3}{|l|}{ Robot Cell Data (Actual) } & \multicolumn{2}{l|}{ Robot Cell Data (GRC) } \\
\cline { 2 - 7 } & $\mathbf{X}(\mathbf{m m})$ & $\mathbf{Y}(\mathbf{m m})$ & $\mathbf{Z}(\mathbf{m m})$ & $\mathbf{X}(\mathbf{m m})$ & $\mathbf{Y}(\mathbf{m m})$ & $\mathbf{Z}(\mathbf{m m})$ \\
\hline $\mathbf{1 .}$ & 169.03 & 0 & 504.33 & 0.610434 & 1 & $3.1 \mathrm{E}-05$ \\
\hline $\mathbf{2 .}$ & 200 & 0 & 20 & 0.530543 & 1 & 0.6 \\
\hline $\mathbf{3 .}$ & 270.01 & 0 & 20.01 & 0.409415 & 1 & 0.428572 \\
\hline $\mathbf{4 .}$ & 340 & 0 & 20 & 0.333333 & 1 & 0.6 \\
\hline $\mathbf{5 .}$ & 149.99 & 149.99 & 19.99 & 0.672713 & 0.491542 & 1 \\
\hline $\mathbf{6 .}$ & 220.01 & 220.01 & 20.01 & 0.489178 & 0.397249 & 0.428572 \\
\hline $\mathbf{7 .}$ & 290 & 290 & 20.01 & 0.384359 & 0.333333 & 0.428572 \\
\hline $\mathbf{8 .}$ & 88.91 & 211.44 & 20.01 & 1 & 0.406801 & 0.428572 \\
\hline $\mathbf{9 .}$ & 305.13 & 120.56 & 20.02 & 0.367343 & 0.546016 & 0.333333 \\
\hline $\mathbf{1 0 .}$ & 315 & 247 & 190 & 0.357032 & 0.369898 & $8.82 \mathrm{E}-05$ \\
\hline
\end{tabular}

(iii) The final step of Grey Relation Grade (GRG) is calculated in single objective conversion by averaging the grey relation coefficients.

Table 4: GRG for the Output

\begin{tabular}{|c|c|c|c|c|c|c|}
\hline \multirow{2}{*}{$\begin{array}{l}\text { Sl. } \\
\text { No. }\end{array}$} & \multicolumn{5}{|c|}{ Joint Coordinates } & \multirow{2}{*}{$\begin{array}{l}\begin{array}{l}\text { Robot Cell } \\
\text { Data }\end{array} \\
\text { GRG } \\
\end{array}$} \\
\hline & $\theta_{1}$ & $\theta_{2}$ & $\theta_{3}$ & $\theta_{4}$ & $\theta_{5}$ & \\
\hline 1. & 0 & $-\overline{120.27}$ & 95.03 & 88.81 & 0 & 0.536822 \\
\hline 2. & 0 & -8.93 & 107.87 & -8.93 & 0 & 0.710181 \\
\hline 3. & 0 & -8.88 & 89.59 & 9.29 & 0 & 0.612662 \\
\hline 4. & 0 & -2.95 & 65.09 & 27.87 & 0 & 0.644444 \\
\hline 5. & 45 & -9.35 & 105.05 & -5.70 & 45.02 & 0.721418 \\
\hline 6. & 45 & -6.17 & 76.21 & 19.95 & 45.02 & 0.438333 \\
\hline 7. & 45 & 14.78 & 20.48 & 54.73 & 45.02 & 0.382088 \\
\hline 8. & 67.19 & -9.63 & 100.80 & -1.17 & 0 & 0.611791 \\
\hline 9. & 21.56 & -4.43 & 69.91 & 24.53 & 0 & 0.415564 \\
\hline 10. & 38.10 & -15.86 & 98.92 & $\begin{array}{l} \\
83.06\end{array}$ & 0 & 0.242339 \\
\hline
\end{tabular}

\section{Prediction Strategies}

\section{Response surface methodology}

The relationship between the three response parameters and five set of experimentation parameters were studied using RSM. Using the Minitab software empirical equations were made for the Grey Relation Grade value prediction using the experimental influencing parameters as mentioned in the equation 3 . Initially defining the custom response surface design through the tab which is shown in the below figure 1 and the low high values of the input parameters were shown in the below figure 2. And finally the proposed design has been analysed using uncoded units as shown in the figure 3 . The predicted GRG values from the developed empirical equation are tabulated in the table 5. From the predicted GRG values the average error obtained is 0.102359 when compared with the actual GRG value.

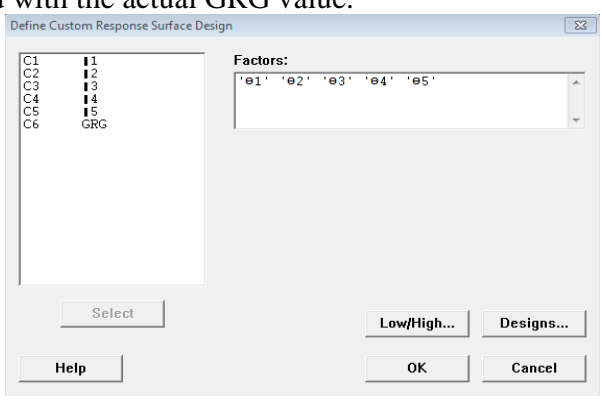

Figure 1: Custom response surface design defining

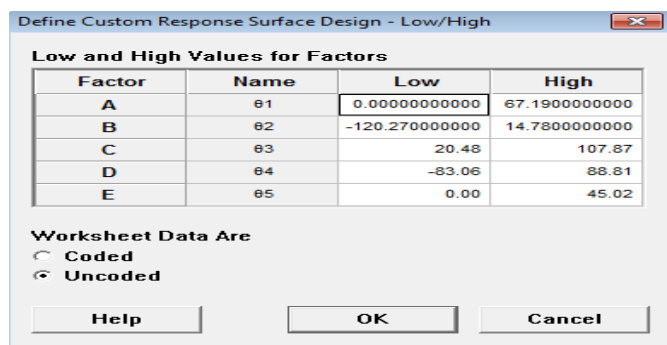

Figure 2: Low high values of input parameters

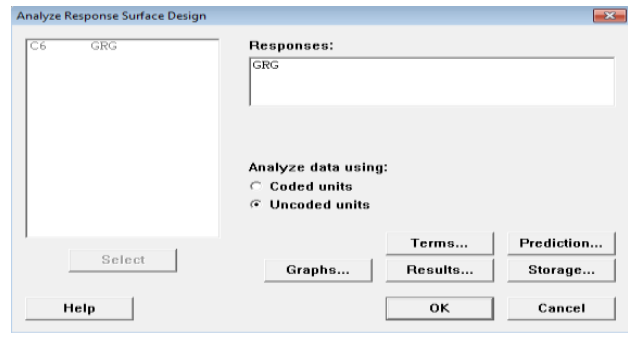

Figure 3: Design analysing

GRG $=-99.5579-0.0099 * \theta 1-1.7639 * \theta 2+0.3275 * \theta 3+1.3893 * \theta 4+0.0037 *$ $\theta 5+0.0001 * \theta 1 * \theta 1-0.0305 * \theta 2 * \theta 2+0.0054 * \theta 3 * \theta 3+0.0159 * \theta 4 * \theta 4$ (3)

Table 5: RSM based Predicted GRG

\begin{tabular}{|c|c|c|c|c|c|c|c|}
\hline \multirow{2}{*}{$\begin{array}{l}\text { Sl. } \\
\text { No } \\
\text {. }\end{array}$} & \multicolumn{5}{|c|}{ Joint Coordinates } & \multicolumn{2}{|c|}{ Robot Cell Data } \\
\hline & $\theta_{1}$ & $\theta_{2}$ & $\theta_{3}$ & $\theta_{4}$ & $\theta_{5}$ & $\begin{array}{l}\text { Actual } \\
\text { GRG }\end{array}$ & $\begin{array}{l}\text { Predicte } \\
\text { d GRG }\end{array}$ \\
\hline 1. & 0 & $\begin{array}{l}- \\
120.2 \\
7\end{array}$ & 95.03 & $\begin{array}{l}88.8 \\
1\end{array}$ & 0 & $\begin{array}{l}0.53682 \\
2\end{array}$ & 0.086308 \\
\hline 2. & 0 & -8.93 & $\begin{array}{l}107.8 \\
7 \\
\end{array}$ & -8.93 & 0 & $\begin{array}{l}0.71018 \\
1 \\
\end{array}$ & 0.784487 \\
\hline 3. & 0 & -8.88 & 89.59 & 9.29 & 0 & $\begin{array}{l}0.61266 \\
2\end{array}$ & 0.662418 \\
\hline 4. & 0 & -2.95 & 65.09 & $\begin{array}{l}27.8 \\
7 \\
\end{array}$ & 0 & $\begin{array}{l}0.64444 \\
4\end{array}$ & 0.645285 \\
\hline 5. & 45 & -9.35 & $\begin{array}{l}105.0 \\
5\end{array}$ & -5.70 & $\begin{array}{l}45.0 \\
2 \\
\end{array}$ & $\begin{array}{l}0.72141 \\
8 \\
\end{array}$ & 0.784922 \\
\hline
\end{tabular}




\begin{tabular}{|l|l|l|l|l|l|l|l|}
\hline $\mathbf{6 .}$ & 45 & -6.17 & 76.21 & $\begin{array}{l}19.9 \\
5\end{array}$ & $\begin{array}{l}45.0 \\
2\end{array}$ & $\begin{array}{l}0.43833 \\
3\end{array}$ & 0.454391 \\
\hline $\mathbf{7 .}$ & 45 & 14.78 & 20.48 & $\begin{array}{l}54.7 \\
3\end{array}$ & $\begin{array}{l}45.0 \\
2\end{array}$ & $\begin{array}{l}0.38208 \\
8\end{array}$ & 0.267498 \\
\hline $\mathbf{8 .}$ & $\begin{array}{l}67.1 \\
9\end{array}$ & -9.63 & $\begin{array}{l}100.8 \\
0\end{array}$ & -1.17 & 0 & $\begin{array}{l}0.61179 \\
1\end{array}$ & 0.661991 \\
\hline $\mathbf{9 .}$ & $\begin{array}{l}21.5 \\
6\end{array}$ & -4.43 & 69.91 & $\begin{array}{l}24.5 \\
3\end{array}$ & 0 & $\begin{array}{l}0.41556 \\
4\end{array}$ & 0.425077 \\
\hline $\mathbf{1 0 .}$ & $\begin{array}{l}38.1 \\
0\end{array}$ & -15.86 & 98.92 & $\begin{array}{l}- \\
83.0 \\
6\end{array}$ & 0 & $\begin{array}{l}0.24233 \\
9\end{array}$ & 0.048029 \\
\hline
\end{tabular}

\section{Adaptive neuro fuzzy inference system}

The ANFIS based hybrid network is created for the proposed model which is shown in the figure 4. At first the input parameter and the corresponding GRG values were loaded in the editor from the workspace. The plotted values of actual output GRG values are shown in the figure 5. From the figure 6 the triangular type is selected with three membership function for network creation. After the creation network the network is trained and the predicted ANFIS output GRG values were plotted in the ANFIS editor which is shown in the figure 7 and 8 . The observed predicted ANFIS GRG values were identified from the rule viewer as shown in the figure 9. The predicted GRG values from the developed ANFIS model were tabulated in the below table 6. From the predicted GRG values the average error obtained is 0.000297 when compared with the actual GRG value.

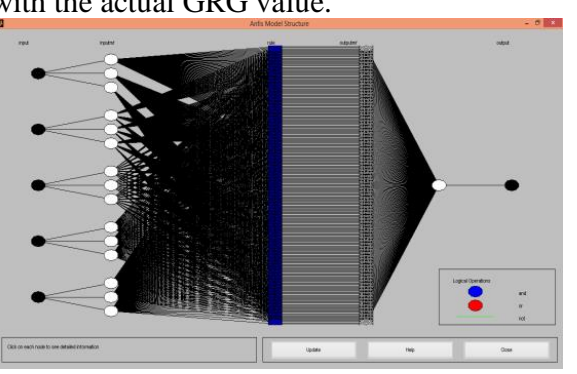

Figure 4: Structure of the proposed model

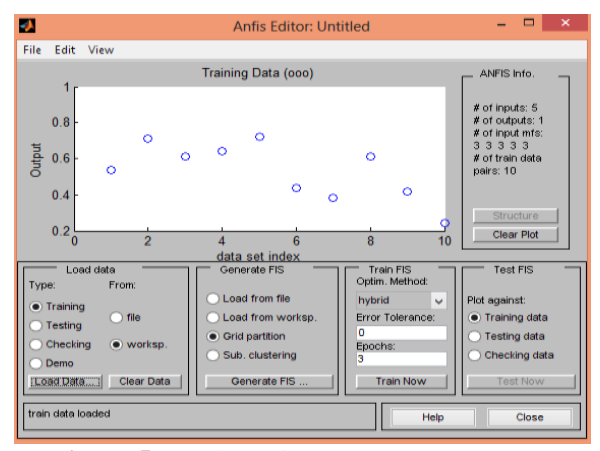

Figure 5: Plotting of actual output responses

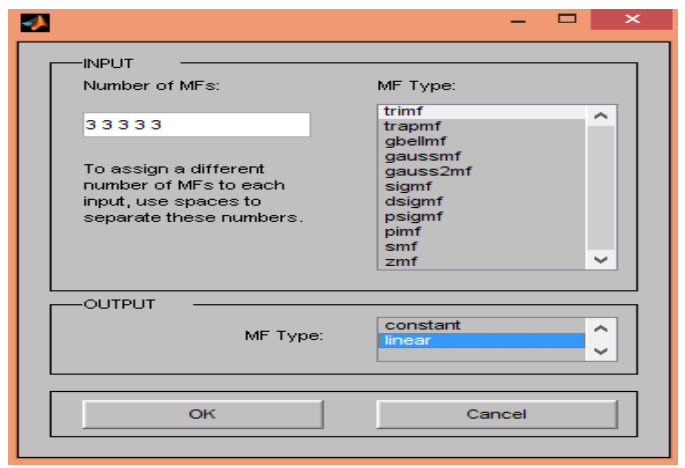

Figure 6: Selection of membership function

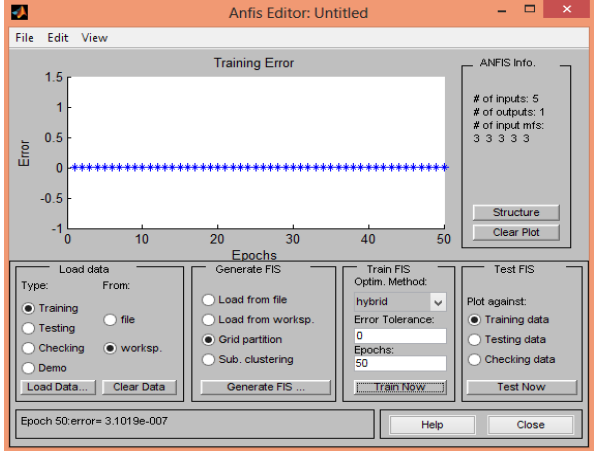

Figure 7: Training of proposed design

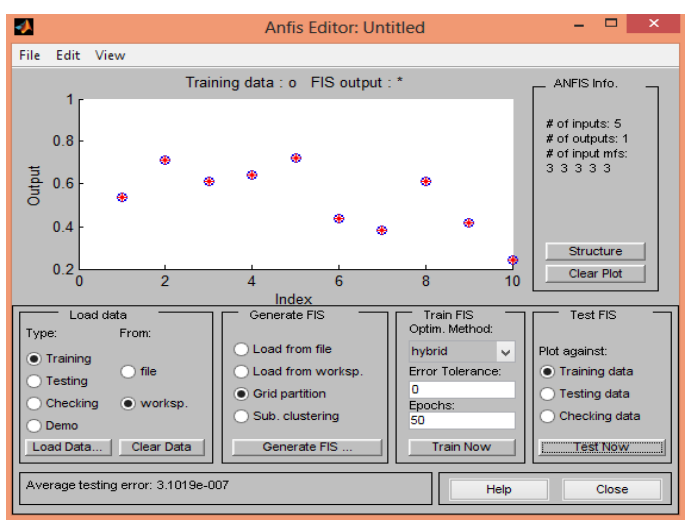

Figure 8: Plotting of actual output

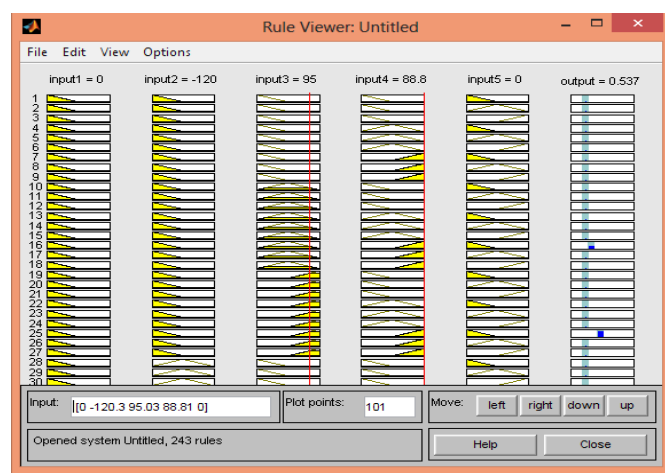

Figure 9: ANFIS rule viewer

Table 5: ANFIS Based Predicted GRG Values

\begin{tabular}{|c|c|c|c|c|c|c|c|}
\hline \multirow{2}{*}{$\begin{array}{l}\text { SI. } \\
\text { No } \\
\text { - }\end{array}$} & \multicolumn{5}{|c|}{ Joint Coordinates } & \multicolumn{2}{|c|}{ Robot Cell Data } \\
\hline & $\theta_{1}$ & $\theta_{2}$ & $\theta_{3}$ & $\theta_{4}$ & $\theta_{5}$ & $\begin{array}{l}\text { Actual } \\
\text { GRG }\end{array}$ & $\begin{array}{l}\text { Predicte } \\
\text { d GRG }\end{array}$ \\
\hline 1. & 0 & $\begin{array}{l}- \\
120.2 \\
7\end{array}$ & 95.03 & $\begin{array}{l}88.8 \\
1\end{array}$ & 0 & $\begin{array}{l}0.53682 \\
2\end{array}$ & 0.537 \\
\hline 2. & 0 & -8.93 & $\begin{array}{l}107.8 \\
7\end{array}$ & -8.93 & 0 & $\begin{array}{l}0.71018 \\
1\end{array}$ & 0.710 \\
\hline 3. & 0 & -8.88 & 89.59 & 9.29 & 0 & $\begin{array}{l}0.61266 \\
2 \\
\end{array}$ & 0.613 \\
\hline 4. & 0 & -2.95 & 65.09 & $\begin{array}{l}27.8 \\
7 \\
\end{array}$ & 0 & $\begin{array}{l}0.64444 \\
4 \\
\end{array}$ & 0.644 \\
\hline 5. & 45 & -9.35 & $\begin{array}{l}105.0 \\
5 \\
\end{array}$ & -5.70 & $\begin{array}{l}45.0 \\
2 \\
\end{array}$ & $\begin{array}{l}0.72141 \\
8 \\
\end{array}$ & 0.721 \\
\hline 6. & 45 & -6.17 & 76.21 & $\begin{array}{l}19.9 \\
5 \\
\end{array}$ & $\begin{array}{l}45.0 \\
2 \\
\end{array}$ & $\begin{array}{l}0.43833 \\
3 \\
\end{array}$ & 0.438 \\
\hline 7. & 45 & 14.78 & 20.48 & $\begin{array}{l}54.7 \\
3 \\
\end{array}$ & $\begin{array}{l}45.0 \\
2 \\
\end{array}$ & $\begin{array}{l}0.38208 \\
8 \\
\end{array}$ & 0.382 \\
\hline 8. & $\begin{array}{l}67.1 \\
9 \\
\end{array}$ & -9.63 & $\begin{array}{l}100.8 \\
0 \\
\end{array}$ & -1.17 & 0 & $\begin{array}{l}0.61179 \\
1\end{array}$ & 0.612 \\
\hline 9. & $\begin{array}{l}21.5 \\
6\end{array}$ & -4.43 & 69.91 & $\begin{array}{l}24.5 \\
3 \\
\end{array}$ & 0 & $\begin{array}{l}0.41556 \\
4\end{array}$ & 0.416 \\
\hline 10. & $\begin{array}{l}38.1 \\
0\end{array}$ & -15.86 & 98.92 & $\begin{array}{l}- \\
83.0 \\
6\end{array}$ & 0 & $\begin{array}{l}0.24233 \\
9\end{array}$ & 0.242 \\
\hline
\end{tabular}




\section{Conclusion}

The research work concluded from the prediction point of view is pointed out here. Both the methods of prediction models have different advantages as well as disadvantages. The proposed models like RSM and ANFIS were also able to identify the position of the robot SCORBOT $5 \mathrm{u}$ plus in future by this proposed developed model. From the predicted GRG values of the two models, ANFIS based hybrid method of prediction has a better result when compared with the RSM based model. Also simulation through ANFIS model is quiet easy one because of self-adapting of rules for the given design model. But a strong drawback identified in this system is only one output response is predicted at a single time, so it will take more simulation time and that should be neglected through the Grey Relation Analysis.

\section{References}

[1] Zhang J \& Cai J, "Error Analysis and Compensation Method of 6axis Industrial Robot", International Journal on Smart Sensing and Intelligent Systems, Vol.6, No.4, (2013).

[2] Rout BK \& Mittal RK, "Tolerance Design of Robot Parameters Using Taguchi Method”, Elsevier, Mechanical Systems and Signal Processing, (2005).

[3] Shiakolas PS, Conrad KL \& Yih TC, "On the Accuracy, Repeatability, and Degree of Influence of Kinematics Parameters for Industrial Robots", International Journal of Modelling and Simulation, Vol.22, No.3, (2002)

[4] Butler S \& Demiris Y, "Predicting the Movements of Robot Teams Using Generative Models", Distributed Autonomous Robotic Systems, Vol.8, (2009), pp.533-542.

[5] Trung TT, Guang LW \& Long PT, "Tolerance Design of Robot Parameters Using Generalized Reduced Gradient Algorithm", International Journal of Materials, Mechanics and Manufacturing, Vol.5, No.2, (2016). 